\title{
Temperature Monitoring of Marsh Landscapes and Development of Exogenous Processes in the West Siberian Plain (Russia)
}

\author{
Sergey Korkin ${ }^{1 *}$, Elena Korkina ${ }^{2}$, Elena Kail ${ }^{3}$ \\ ${ }^{1}$ Scientific Laboratory of "Geo-Ecological Research", Nizhnevartovsk State University, 56, Lenin St., \\ Nizhnevartovsk, 628602, Russia \\ ${ }^{2}$ Department of Geography, Faculty of Ecology and Engineering, Nizhnevartovsk State University, 56, Lenin \\ St., Nizhnevartovsk, 628602, Russia \\ ${ }^{3}$ NIPIGAS, 18/1, Kruchinin St., 676450, Svobodny \\ "Corresponding author: korkin.nsu@bk.ru
}

Received: $21^{\text {st }}$ February, 2018

Accepted: $12^{\text {th }}$ June, 2018

\begin{abstract}
The research touches upon marsh landscapes in the context of temperature monitoring and in connection with exogenous processes during engineering intervention. The monitoring of temperature regimes was conducted in the mid-taiga subzone of marsh landscapes for revealing the dynamics of exogenous processes. The authors used the method of recording systems for the field measurement of the temperature of the peat and underlying soils. The measurements were conducted on a territory that belongs to the middle taiga landscapes of Western Siberia. The authors of the research analyze the data obtained from thermowells 5, 5a and 6. During the observation period of 2015-2016, the average annual temperature was $8.3^{\circ} \mathrm{C}$ for thermowell 5a (technogenic area), which is $3.8^{\circ} \mathrm{C}$ and $4.2^{\circ} \mathrm{C}$ higher than the average annual values of thermowell 5 and thermowell 6 respectively. The latter belongs to natural marsh landscapes. Observations conducted in 2016-2017 confirmed this fact with a difference of $4.8^{\circ} \mathrm{C}$ and $3.7^{\circ} \mathrm{C}$ for thermowells 5 and 6 respectively. As compared to natural marsh landscapes not affected by manmade impact, a higher temperature was observed on soils, which affects the manifestation of exogenous processes.
\end{abstract}

Key words: temperature monitoring; marsh landscapes; exogenous processes; technogenic impact; engineering impact

\section{Introduction}

Marsh landscapes occupy a fairly large part (more than $35 \%$ ) of the territory of the taiga zone of Western Siberia. The marshland of individual landscape provinces is more than $70 \%$. Marshes support the stability of the habitat and the growth of plants and animals, thus ensuring the preservation of their gene pool. The geomorphological functions of marshes are manifested in the processes of equalizing the primary forms of the relief, which is a favourable anti-erosion factor. Marshes participate in the formation of the thermal and water balance of vast territories, which has a significant impact on the climate (Lopatina, 2012). This territory is subject to intensive engineering development, which leads to the violation of natural conditions. Since marsh landscapes are very susceptible to anthropogenic load, this can lead to adverse consequences for humans. Engineering development results in a change in surface conditions, in a succession change and, as a rule, in changes in soil temperatures and properties, which, in turn, can lead to a complex of exogenous processes. 
Melnikov et al. (2016) note the dependence of soil temperatures on landscapes. In their studies, a number of scientists, in particular, Pavlov (2008), Vasiliev et al. (2016), and Orekhov (2008) indicate that the response of the upper horizons of the lithosphere to modern climate changes strongly depends on the landscape-geological conditions. In addition, they point to the existence of a certain correspondence between the parameters of frozen rocks and the hierarchical level of landscapes. This leads to a holistic understanding of the responsiveness and interaction between the atmosphere of the ocean and the land in the Northern Eurasian region (Lappalainen et al., 2016). Like any dynamic geosystem, the marsh landscape has its own cycles, stages of development and the limit of stability. For marsh landscapes, temperature parameters of soils have the greatest influence on the manifestation of exogenous processes in the context of exogenous relief formation. Soil temperature is a key factor that controls many biotic and antibiotic processes occurring in soils, in particular, vegetation growth and productivity, decomposition and mineralization of soil organic matter, emission of greenhouse gases (Prokushkin and Guggenberger, 2007), and separation of dissolved organic carbon (Dyukarev, 2017). The mid-taiga subzone of Western Siberia is located within the island distribution of permafrost. An important indicator obtained is related to the dynamics of soil temperature at key sites (Korkin et al., 2015). It is necessary to pay attention to the selfhealing processes of the Middle Ob River disturbed by technogenesis (Korkina, 2015). The natural landscapes of the Middle $\mathrm{Ob}$ Region (Korkin et al., 2016; 2017) and the Siberian Reefs (Sheinkman et al., 2016) are comprehensivelyexamined, and especially the conditions of modern temperature monitoring are touched upon. The aim of the research is to monitor the temperature patterns for marsh landscapes in the middle taigs subzone of the West Siberian Plain in order to identify the dynamics of exogenous processes during the engineering development of this territory and the analysis of the impact of climatic parameters on global changes.

\section{Research area}

The research was carried out in the Sredneobsky Lowland, which occupies the eastern part of the West Siberian Plain, within the latitudinal course of the Ob River (Fig.1) between 60 and $64^{\circ} \mathrm{N}$ and between 72 and $78^{\circ} \mathrm{E}$. The terrain of this territory is flat-leveled with prevailing heights from 40 to $80 \mathrm{~m}$ and from 100 to $120 \mathrm{~m}$ above the Baltic Sea level on watersheds. The main stream flow of the research territory is the Middle Ob River, from the mouth of the Svetlaya waterway to the Lokosovskaya waterway. In the Nizhnevartovsk Region, the Middle $\mathrm{Ob}$ has a length of $134 \mathrm{~km}$ and the width of the bottomland varies from 18 to $20 \mathrm{~km}$. Climate plays a leading role in the development of exogenous processes of relief-formation. The most important meteorological factors for the research area include the variation of air temperature, the amount and annual distribution of precipitation, as well as wind patterns. The major relief-forming processes are manifested in warm weather under conditions of positive values of air and soil temperatures, as well as liquid precipitation. The warm period starts when average monthly temperatures exceed 0 ${ }^{\circ} \mathrm{C}$, which mainly takes place in early May. Cold and snowy weather starts when average daily temperatures drop below $0{ }^{\circ} \mathrm{C}$ at the end of September to the middle of October. According to long-term data, a high average monthly temperature - up to $+26.7{ }^{\circ} \mathrm{C}-$ is recorded in June. The average annual temperature of air in the $\mathrm{Ob}$ River is $-2.3{ }^{\circ} \mathrm{C}$. The annual precipitation for the $\mathrm{Ob}$ Valley varies from 225 to $722 \mathrm{~mm}$. In the research area, winds of western and south-western direction prevail, and the frequency of these rhumbs is about $17 \%$ per year. For the taiga forests of the middle taiga, the zonal types include spruce and 
cedar trees, which were replaced (by felling and logging) by secondary forests with dark coniferous, pine, and small-leaved trees. In the vegetation cover of the oligotrophic marshes of the research area sphagnum pine and shrub complexes with small lakes and sphanum mosses prevail and involve Ledum-cassandrasphagnum groups with pines, as well as cedars on the ridge of forests.

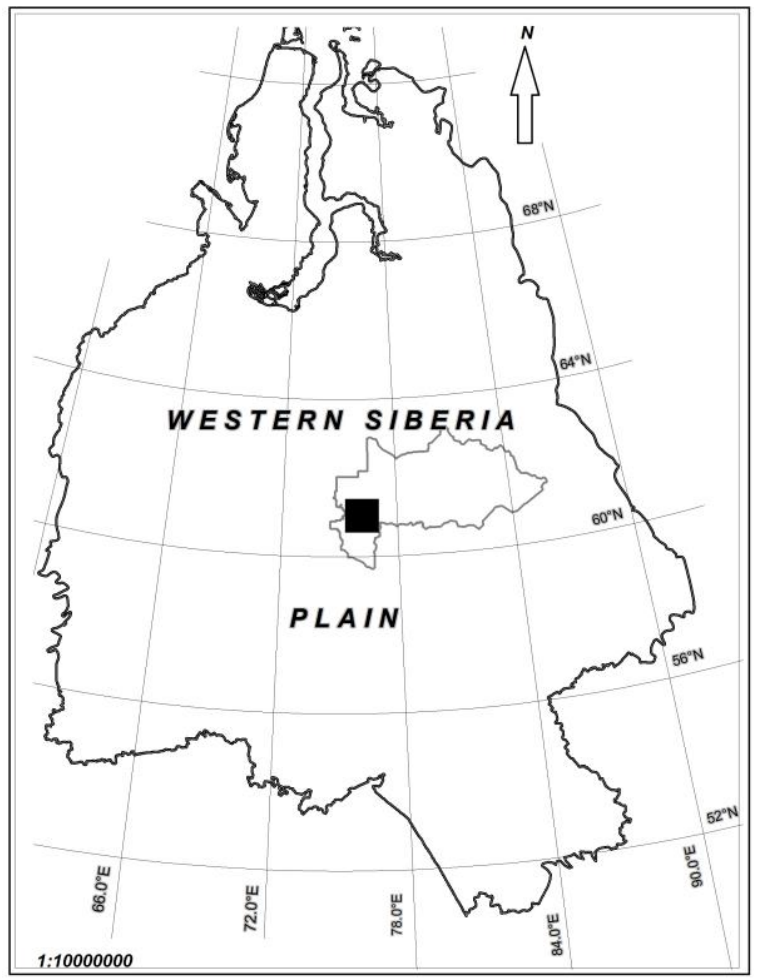

Fig.1. Area for Marsh Landscape Research (the Black Square Denotes the Actual Research Location).

\section{Materials and Methods}

The goal of the research is to monitor the temperature patterns for marsh landscapes under conditions of exogenous relief-formation. The key area presented in this article is equipped with thermowell 5 (natural control area with observation periods of 2015-2016 and 2016-2017), 5a (technogenic area with observation periods of 2015-2016 and 20162017) and thermowell 6 (natural control area with observation periods of 2013-2014, 20142015, 2015-2016, and 2016-2017). Due to the high intensity of the technogenic impact associated with oil production, thermowells were laid on marsh landscapes in natural conditions and on marsh landscapes in conditions susceptible to technogenic impact (in the collector corridor of pipelines). The natural marsh landscape of this key area corresponds to temperature well (thermowell) 6 with depths of $20,40,60 \mathrm{~cm}, 1,2$, and $3 \mathrm{~m}$ activated on 15.11.2010, temperature well 5 with depths of 20,40 , and $60 \mathrm{~cm}$, and temperature well $5 \mathrm{a}$ with a technogenic effect and analogous depths.

Thermowell 5 was first launched in 2010 . After eliminating technical problems, an updated launch was made in the fall of 2015. The air temperature for this key area was obtained using a recorder installed in the vicinity of thermowell 6 . The authors of this research used methods of recording systems for the actual measurement of soil temperature. This method is described in detail by Popov et al. (2017), Kazantsev (2017), Konstantinov et al. (2011). Investigations dealing with the features of the temperature regime of the peat deposit of the oligotrophic marsh in the southern taiga of Western Siberia are presented in the works of E.A. Dyukarev (2017). The results of the measurements of air and soil temperatures on the monitoring network during the implementation of the German-Russian project "Kulunda" cause a great scientific interest as research methods (Belyaev et al., 2017).

The international experience of studying the temperature regime of soils is of great importance for setting up monitoring (Zang et al., 2005; Wisser et al., 2011; Sheng et al., 2004). A temperature recorder of type DS1921G-F5 with a temperature range from $40{ }^{\circ} \mathrm{C}$ to $+85^{\circ} \mathrm{C}$ and a sensitivity of $0.5^{\circ} \mathrm{C}$ was used to measure soil temperature at depths of 20, 40, $60 \mathrm{~cm}$ and $1 \mathrm{~m}$. For depths of more than $1 \mathrm{~m}$, DS1921Z-F5 with recorded temperatures ranging from $-5{ }^{\circ} \mathrm{C}$ to $+26{ }^{\circ} \mathrm{C}$ and a sensitivity of $0.125^{\circ} \mathrm{C}$ was used. A thermocouple of type DS1921G-F5 was used to fix the air 
temperature. The frequency of registration of all used loggers is 4 hours. 5-6 measurements were carried out to analyze the diurnal course. Mean daily and monthly values of soil and air temperatures were calculated based on the observation data. The recorders had protective capsules that excluded any violation of sensitivity with immersion in the wells equipped with a casing polyethylene pipe (50 $\mathrm{mm}$ in diameter) with thermal insulation in the wellhead. The data was obtained by reading the recorded information in the fall of the year. The full-scale data on the temperature regime of peat soils and air presented below is analyzed using the Microsoft Office Excel 2007 software product. As a result of the operation of this equipment, the following technical problems were identified: a) for soils in the region of study, the sufficient recorded temperatures range from $-5{ }^{\circ} \mathrm{C}$ to $+26{ }^{\circ} \mathrm{C}$ with a sensitivity of $0.125{ }^{\circ} \mathrm{C}$, which allows more accurate calculation of the mean values per day, month, season and year, b) it is necessary to use thermocosmetics with an output channel for communication media.

\section{Results}

The presented article analyzes the data of four observation seasons: a) 2013-2014; b) 20142015, and c) 2016-2017 for thermowell 6 (natural control area) and includes an analysis of air temperature. For technical reasons, the data related to thermowells 5 and $5 \mathrm{a}$ was obtained during two observation seasons: a) 2015-2016 and b) 2016-2017. This work does not provide a detailed analysis of the obtained parameters of soil and air temperatures for the period of 2010-2013 since the latter was previously published (Liss et al., 2001). The authors of the research choose this series of observations to identify the natural trend of changes in the temperatures of air and peat soils as one of the main factors of exogenous relief formation and engineering impact. For the study period (2013-2016), the air temperature in
January had the following values: $-22.3{ }^{\circ} \mathrm{C}$ (2013-2014), - $19.2{ }^{\circ} \mathrm{C}$ (2014-2015), -21.9 ${ }^{\circ} \mathrm{C}$ (2015-2016), and $-21.3{ }^{\circ} \mathrm{C}$ (2016-2017), which corresponds to the average long-term data of $22.5^{\circ} \mathrm{C}$. In the cold snowy period of 2013-2014, February - but not January - was the coldest month with a temperature of $-24.6{ }^{\circ} \mathrm{C}$. In 20142015 , the warmest month was June with a mean monthly temperature of $19.2^{\circ} \mathrm{C}$, while July was $2.3{ }^{\circ} \mathrm{C}$ colder (Tab.1). The mean annual temperature was $-0.6{ }^{\circ} \mathrm{C}(2013-2014), 0.2{ }^{\circ} \mathrm{C}$ (2014-2015), and $1.3{ }^{\circ} \mathrm{C}$ (2015-2016). According to the meteorological station of the city of Nizhnevartovsk, the mean annual air temperature was $-2.3{ }^{\circ} \mathrm{C}$ from 1998 to 2004 . Analyzing the results demonstrated in Table 1, the authors came to the conclusion that the mean annual temperature obtained positive values during the observation periods of 2014-2015 and 2015-2016. In 2016-2017, there was a decrease in the mean annual temperature, which was due to the cold winter, when the minimum temperature values reached $-21.7{ }^{\circ} \mathrm{C}$ in December.

The data in Table 1 evidences the transition to the positive values of the mean annual temperature during the observation periods of 2014-2015 and 2015-2016. The period of 20162017 saw the return to the negative values.

Temperature is a key factor in exogenous relief formation, which affects the growth, productivity and decomposition of vegetation. The authors analyzed the mean annual and monthly temperatures recorded in the key area of the middle taiga subzone in Western Siberia. The results of monitoring the temperatures of the soils on the marsh reflect the general patterns of the arrival and consumption of solar radiation.

The mean annual temperature for thermowell 6 (Tab.2) has a positive indicator for the observation period considered in this study. The highest mean annual temperature, $4.8^{\circ} \mathrm{C}$, was registered in 2015-2016, while the lowest indicator, $3.7^{\circ} \mathrm{C}$, was observed in 2013-2014, which generally correlates with the mean 
annual air temperature (Tab.1). These indicators depend on the mean annual temperature.

A temperature transition through $0{ }^{\circ} \mathrm{C}$ was observed at a depth of $20 \mathrm{~cm}$ during the observation periods of 2015-2016 and 20162017, as well as at a depth of $60 \mathrm{~cm}$ and $1 \mathrm{~m}$ during the observation period of 2016-2017.

Figures 2 and 3 reflect the singularities of temperature variation at different depths. During the observation period of 2015-2016, high temperatures were recorded in July. In the middle taiga subzone of Western Siberia, the average temperature for the 4 periods was $4.4^{\circ}$ $\mathrm{C}$ in thermowell 6.

To study the impact of engineering development of marsh landscapes, thermowell 5 was updated at the technogenic facility 5 a (the area of the Samotlor-Nizhnevartovk oil pipeline) in 2015. The temperature of the transported oil is $17^{\circ} \mathrm{C}$ through a pipe with a diameter of $1220 \mathrm{~mm}$ laid at a depth of $1 \mathrm{~m}$ from the surface of the upper ridge-moss marsh. The well is located in the immediate vicinity of the pipeline, and thermowell 5 is drilled in 20 meters. In thermowell 5, the mean annual temperature had a positive value of $4.2^{\circ} \mathrm{C}$ for the period of $2015-2016$ and $-4.3{ }^{\circ} \mathrm{C}$ for the period of $2016-2017$, which is $3.8^{\circ} \mathrm{C}$ and $4.0^{\circ} \mathrm{C}$ lower in thermowell $5 \mathrm{a}$ for the periods of 2015 2016 and 2016-2017 respectively (Tab.3).

Comparing the data obtained from the two wells, several differences are observed. At a depth of $20 \mathrm{~cm}$, the mean annual temperature is $2.3{ }^{\circ} \mathrm{C}$ warmer in thermowell 5a. After considering all the depths, it is possible to state that the recorded tendency is maintained with the following values: $40 \mathrm{~cm}-3.9^{\circ} \mathrm{C}, 60 \mathrm{~cm}$ $4.1{ }^{\circ} \mathrm{C}, 1 \mathrm{~m}-5.1{ }^{\circ} \mathrm{C}$, and $2 \mathrm{~m}-3.8^{\circ} \mathrm{C}$. At a depth of $20 \mathrm{~cm}$, the mean annual temperature was $2.3{ }^{\circ} \mathrm{C}$ warmer in thermowell $5 \mathrm{a}$ for the observation period of 2016-2017. The recorded tendency is maintained with the following values: $40 \mathrm{~cm}-4.7^{\circ} \mathrm{C}, 60 \mathrm{~cm}-5.0^{\circ} \mathrm{C}, 1 \mathrm{~m}-4.8$ ${ }^{\circ} \mathrm{C}$, and $2 \mathrm{~m}-4.2{ }^{\circ} \mathrm{C}$.

For more clarity, Figures 4 and 5 demonstrate a summary graph of the mean temperatures for the depths of thermowells 5 (natural landscape) and 5a (technogenic landscape), and Figures 5 and 6 show a summary graph of the mean monthly temperatures for depths from $0.2 \mathrm{~m}$ to $2 \mathrm{~m}$ during the observation period of 2016-2017.

Tab.1. Data of the Basic Air Temperature Parameters

\begin{tabular}{ccccc}
\hline month / time period & $2013-2014$ & $2014-2015$ & $2015-2016$ & $2016-2017$ \\
\hline December & -10.9 & -12.8 & -14.5 & -21.7 \\
January & -22.3 & -19.2 & -21.9 & -21.3 \\
February & -24.6 & -10.9 & -8.6 & -15.7 \\
June & 14.9 & 19.2 & 19.2 & 18.9 \\
July & 16.4 & 16.9 & 20.0 & 17.4 \\
August & 14.5 & 12.9 & 17.4 & 15.6 \\
mean annual & -0.6 & 0.3 & 1.3 & -1.0 \\
sum of positive temperatures & 1907.6 & 2176.5 & 2541.2 & 2096.6 \\
sum of negative temperatures & 2041.4 & 2081.6 & 2064.3 & 2424.4 \\
\hline
\end{tabular}


Tab.2. Mean Annual Soil Temperature Parameters for Thermowell 6 (Natural Area)

\begin{tabular}{|c|c|c|c|c|c|c|c|c|c|c|c|c|}
\hline \multirow{2}{*}{$\begin{array}{l}\text { depth } \\
\text { / time } \\
\text { period } \\
\mathrm{m}\end{array}$} & \multicolumn{3}{|c|}{ 2013-2014 } & \multicolumn{3}{|c|}{ 2014-2015 } & \multicolumn{3}{|c|}{$2015-2016$} & \multicolumn{3}{|c|}{ 2016-2017 } \\
\hline & avg. & $\max$ & $\min$ & avg. & $\max$ & $\min$ & avg. & $\max$ & $\min$ & avg. & $\max$ & $\min$ \\
\hline 0.2 & 3.5 & 12.7 & 0.0 & - & - & - & 5.7 & 18.2 & -0.2 & 5.0 & 18.5 & -1.0 \\
\hline 0.4 & 4.0 & 11.1 & 0.4 & 5.2 & 13.7 & 0.1 & 5.6 & 15.2 & 0.4 & 5.1 & 15.5 & 0.0 \\
\hline 0.6 & 3.5 & 9.2 & 0.2 & 4.5 & 11.6 & 0.0 & 4.7 & 12.4 & 0.0 & 4.3 & 12.4 & -0.5 \\
\hline 1 & 3.8 & 9.2 & 0.5 & 4.7 & 11.1 & 0.5 & 4.9 & 11.7 & 0.6 & 4.6 & 11.5 & -0.1 \\
\hline 2 & 3.7 & 5.5 & 2.3 & 3.9 & 6.1 & 2.3 & 4.1 & 6.1 & 2.5 & 4.1 & 6.4 & 1.9 \\
\hline 3 & 3.7 & 4.4 & 3.0 & 3.8 & 4.6 & 3.0 & 4.0 & 4.8 & 3.3 & 4.2 & 5.0 & 3.4 \\
\hline $\begin{array}{c}\text { mean } \\
\text { annual }\end{array}$ & 3.7 & & & 4.4 & & & 4.8 & & & 4.6 & & \\
\hline
\end{tabular}

Tab.3. Soil Temperatures for Thermowells 5 and 5a for 2015-2016 and 2016-2017

\begin{tabular}{ccccc}
\hline \multirow{2}{*}{$\begin{array}{c}\text { measurement } \\
\text { depth, } \mathrm{m}\end{array}$} & \multicolumn{3}{c}{$\mathrm{t}^{\circ} \mathrm{C}$} \\
\cline { 2 - 5 } & $2015-2016$ & $2016-2017$ & $2015-2016$ & thermowell 5a \\
\cline { 2 - 5 } & 4.6 & 4.2 & 6.9 & 5.7 \\
0.2 & 3.6 & 3.7 & 7.5 & 8.4 \\
0.6 & 4.2 & 4.3 & 8.3 & 9.3 \\
1 & 4.2 & 4.6 & 9.3 & 9.4 \\
2 & 4.5 & 4.6 & 8.3 & 8.8 \\
\hline mean annual & 4.2 & 4.3 & 8.0 & 8.3 \\
\hline
\end{tabular}

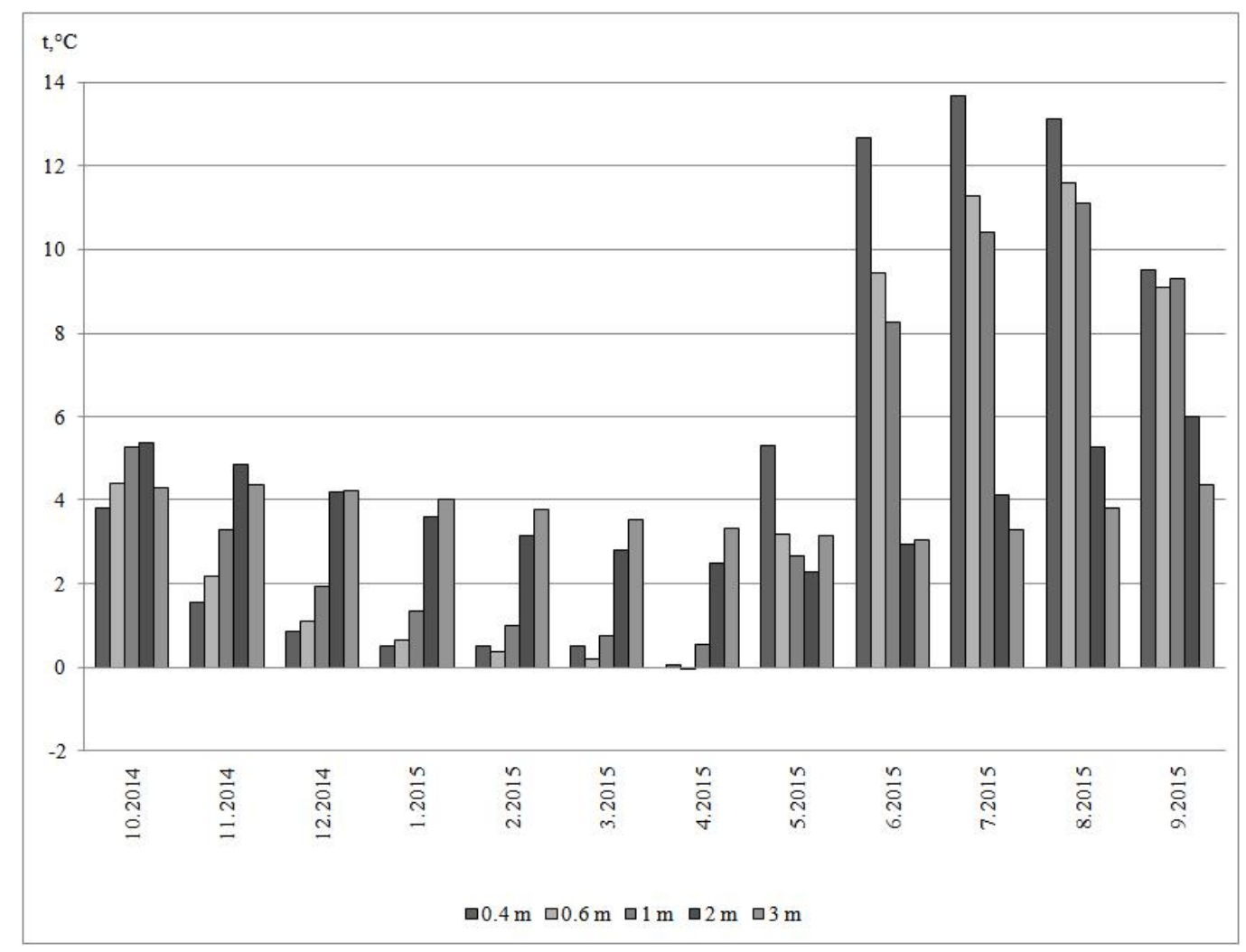

Fig.2. Soil Temperature for Thermowell 6 (Natural Area) for 2014-2015 


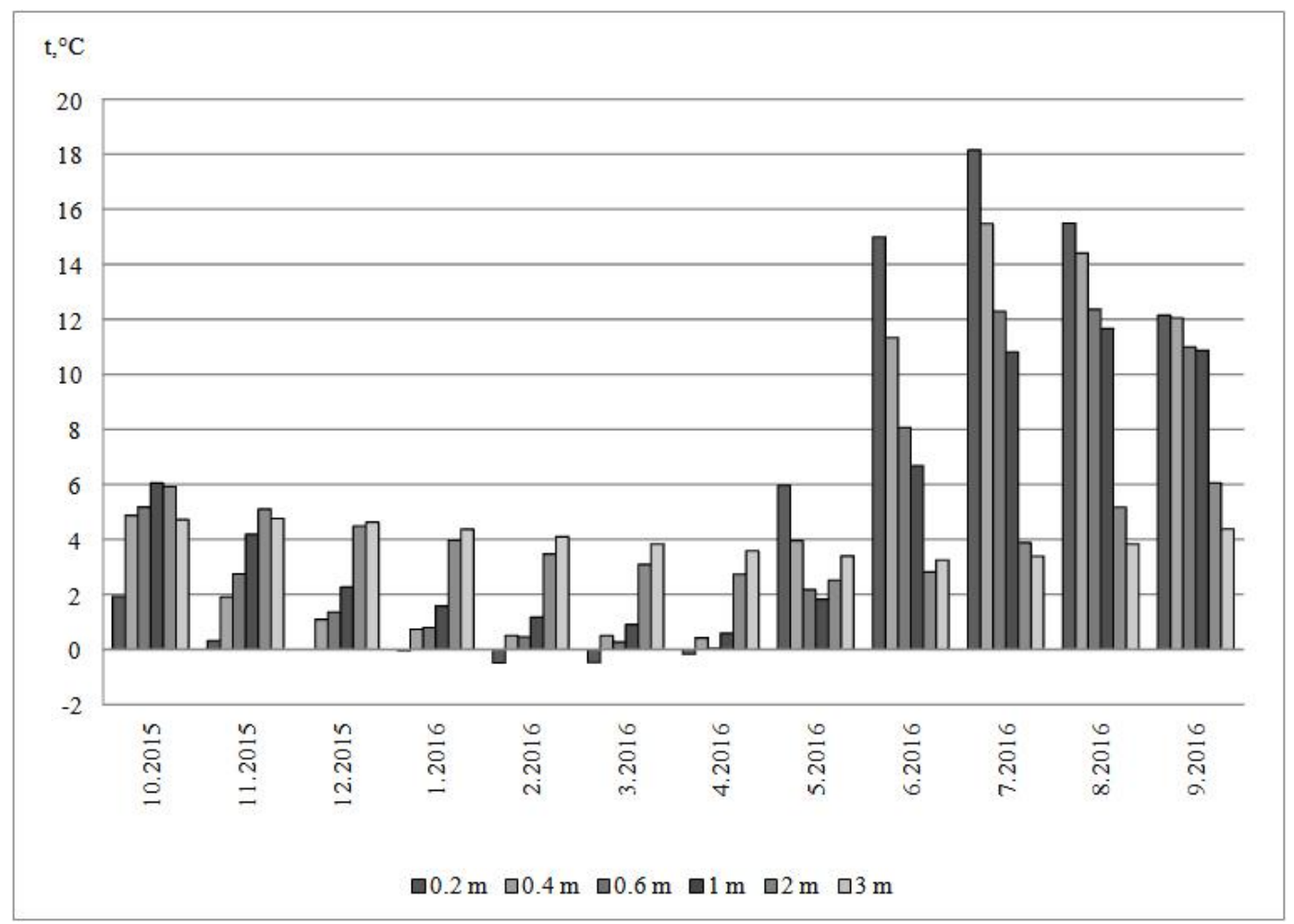

Fig.3. Soil Temperature for Thermowell 6 (Natural Area) for 2015-2016

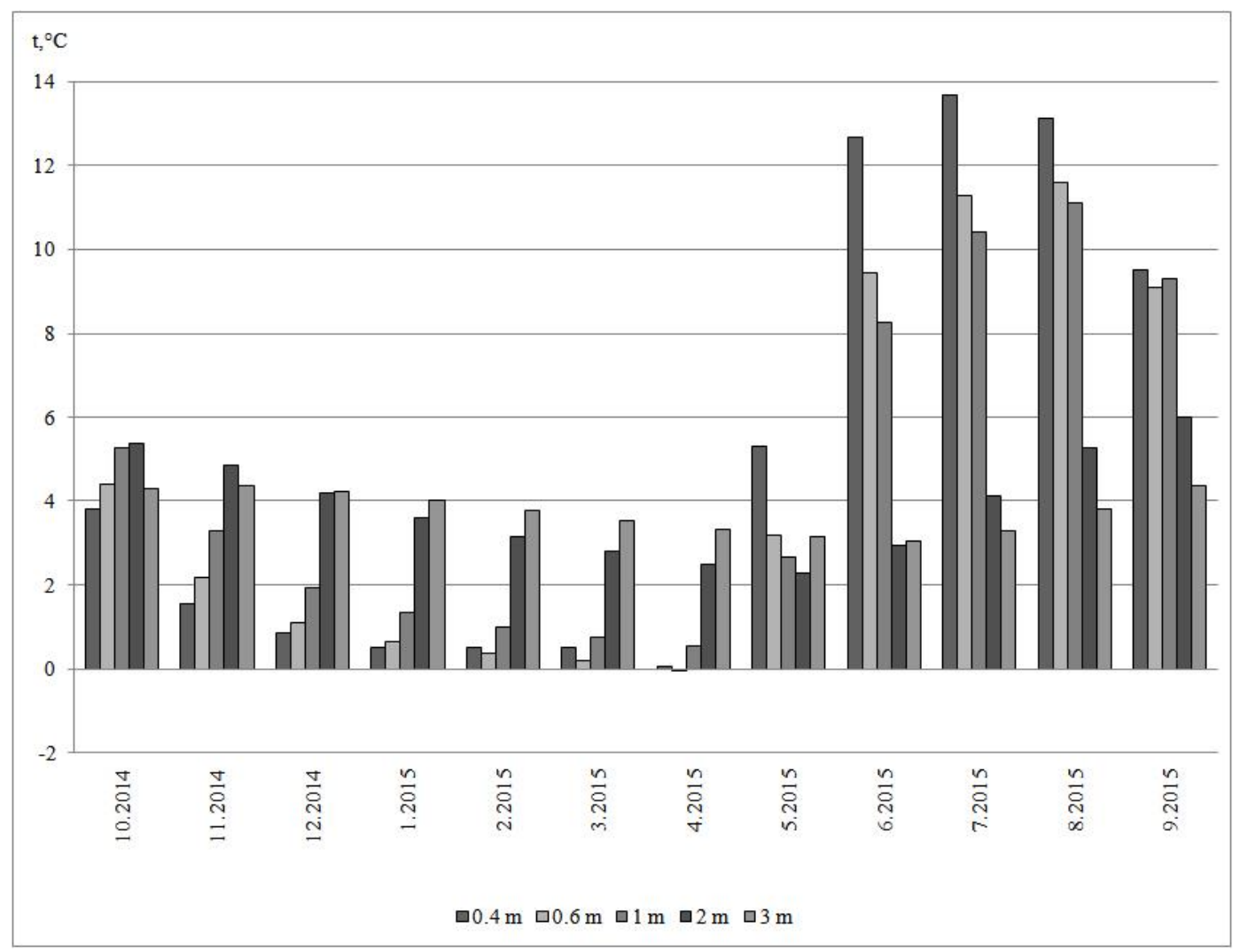


Fig.4. Mean Temperatures for Thermowells 5 (Natural Area) for 2015-2016

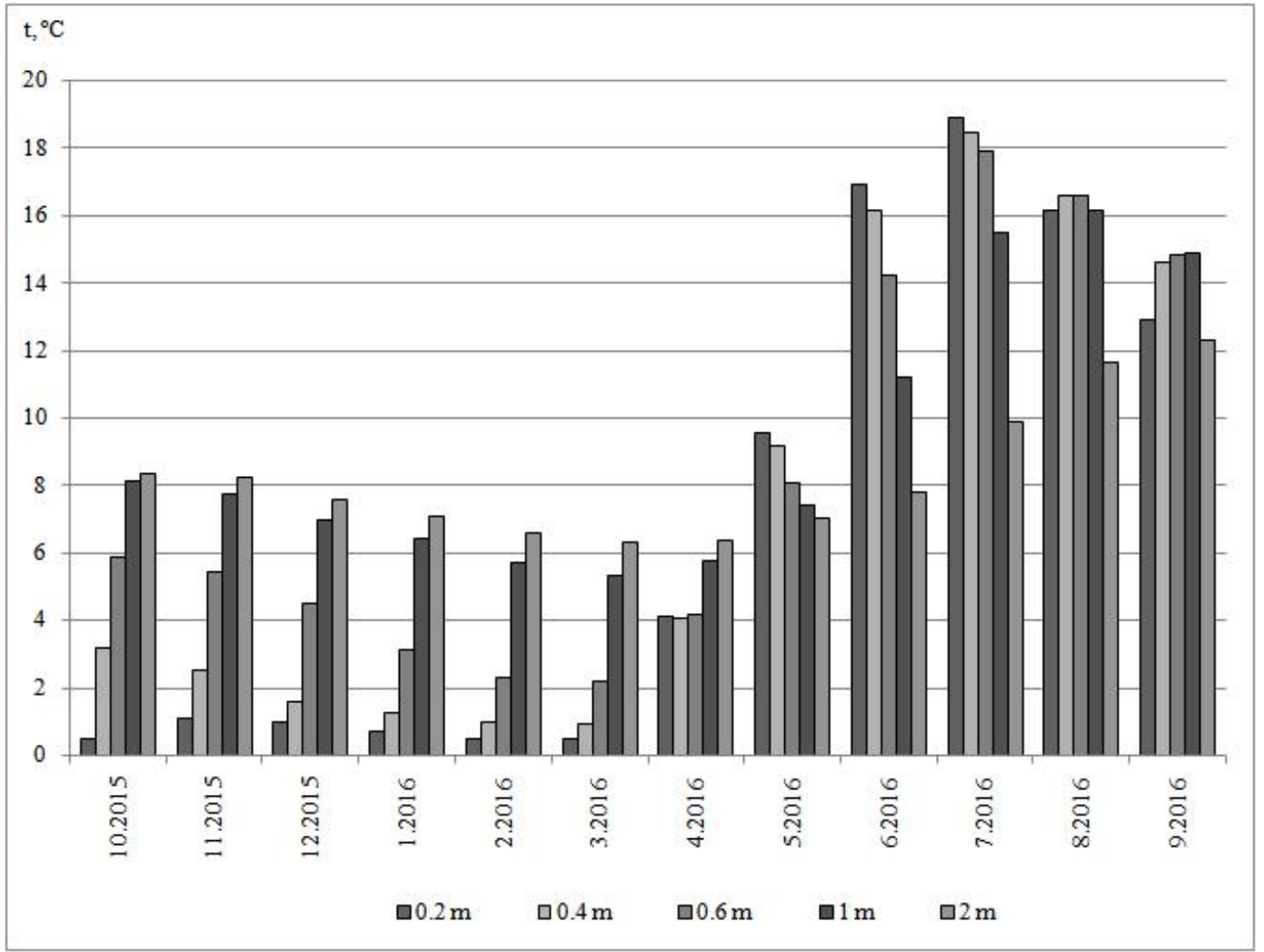

Fig.5. Mean Temperatures for Thermowells 5a (Natural Area) for 2015-2016

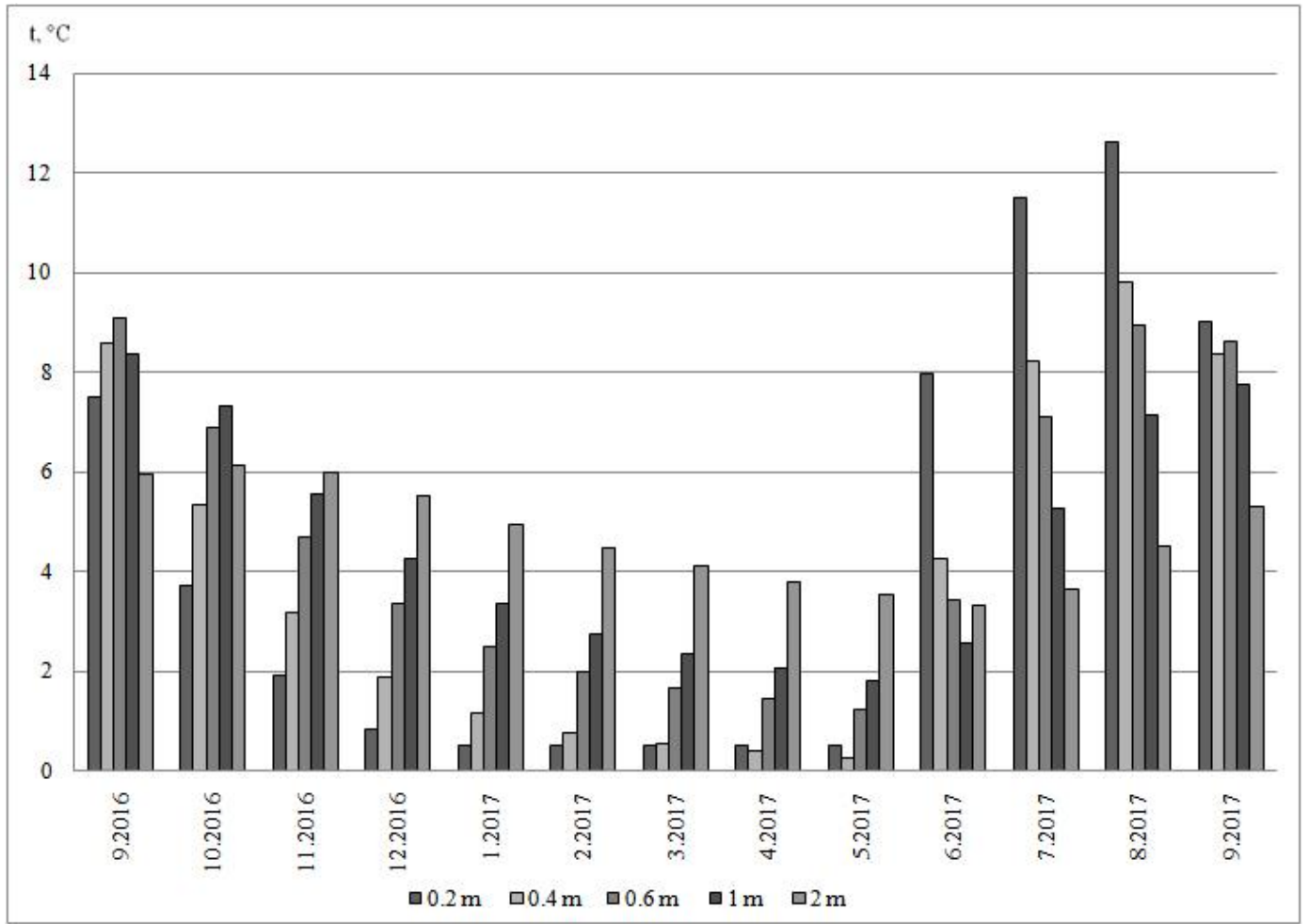

Fig.6. Mean Temperatures for Thermowells 5 (Natural Area) for 2016-2017 


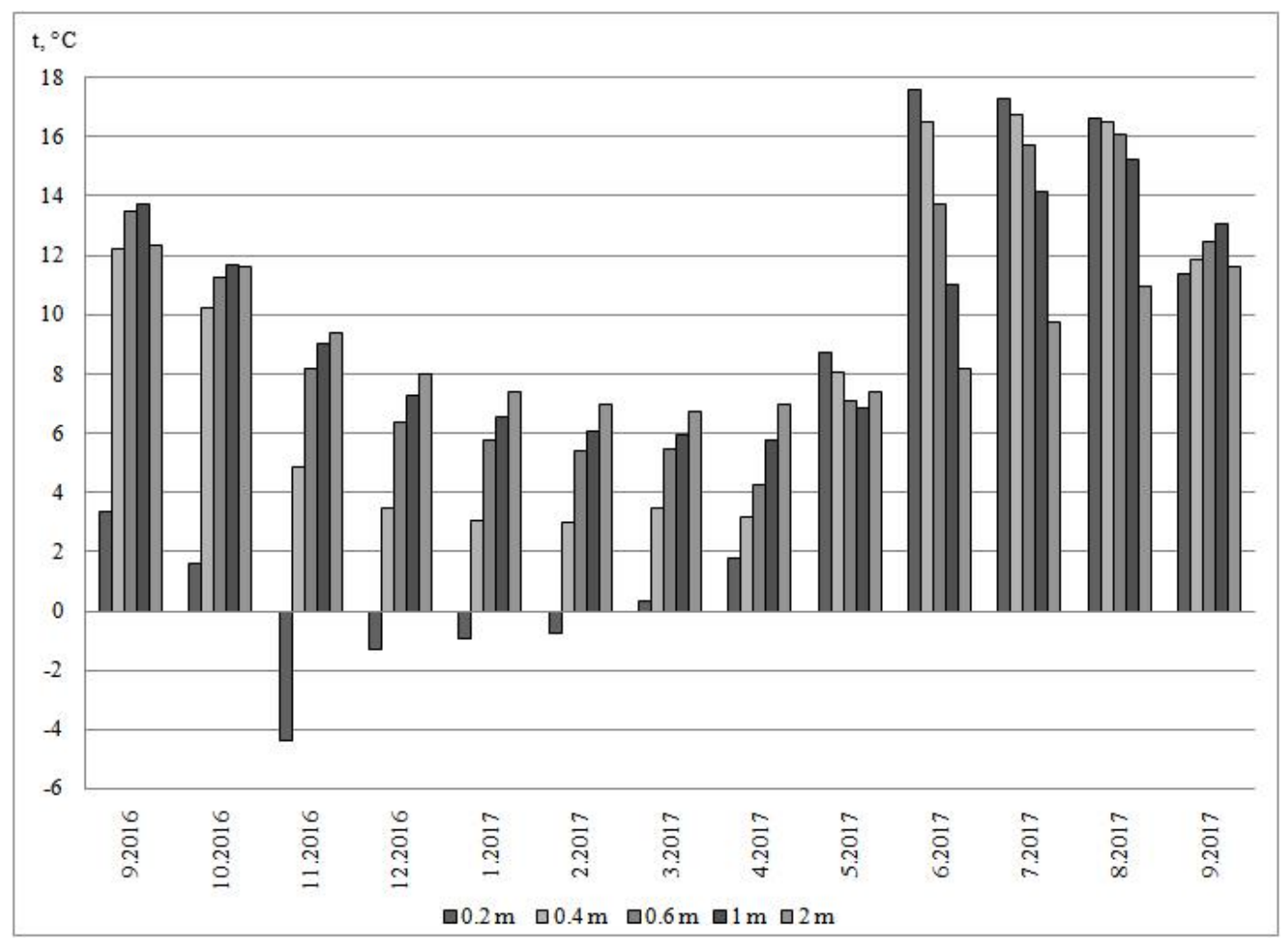

Fig.7. Summary Graph of Mean Temperatures for Thermowell 5a (Technogenic Area) for 2016-2017

\section{Discussions}

Like any dynamic geosystem, the marsh landscape has its own cycles, stages of development and the limit of stability. For marsh landscapes, temperature parameters of soils have the greatest influence on the manifestation of exogenous processes in the context of biogenic relief formation. For the observation period of 2015-2016, the mean annual temperature had a value of $8.3{ }^{\circ} \mathrm{C}$ at all depths for thermowell 5a (technogenic area), which is $3.8^{\circ} \mathrm{C}$ above the mean annual values of thermowell 5 and $4.2{ }^{\circ} \mathrm{C}$ above the mean annual values of thermowell 6 , which belong to natural marsh landscapes. Observations conducted in 2016-2017 confirmed this fact with a difference of $4.8{ }^{\circ} \mathrm{C}$ and $3.7{ }^{\circ} \mathrm{C}$ for thermowells 5 and 6 respectively. Well 6 is located $10 \mathrm{~km}$ to the south-west of well 5 and corresponds to the natural area for a long period of observation. In thermowell 5 , the mean annual temperature is $0.6{ }^{\circ} \mathrm{C}$ and $0.3{ }^{\circ} \mathrm{C}$ lower than in thermowell 6 for the periods of 20152016 and 2016-2017 respectively.

The collective monograph of O. L. Liss, L. I. Abramova and N. A. Avetova discloses the unified concept of the marsh formation process and presents the average rates of vertical peat accumulation: $0.37 \mathrm{~mm} /$ year for the northern taiga and $0.57 \mathrm{~mm} /$ year for the middle taiga. The data concerning the marshland surrounding Lake Samotlor is $-0.32 \mathrm{~mm} /$ year, the age of peak thickness being $7700 \pm 60$ years and the average thickness being $2.5 \mathrm{~m}$ (Liss et al., 2001). The presented reduced rate of peat accumulation cannot be the same for the entire marshland due to the differences observed in the hollows, ridges and lakes. This rate is a general quantitative indicator. Currently, bogging occurs due to the growth of existing marsh systems in the vastness, and the emergence of new bogging foci in natural conditions is quite rare. New bogging foci arise as a consequence of man-made impact, in particular, the absence of spillway structures in the places of roads, oil 
and gas pipelines, as well as stagnation of small rivers and streams.

\section{Conclusions}

Based on the results of the research, it is possible to conclude that the heating capacity of engineering facilities for pipeline transport is limited by protection in a zone of $25 \mathrm{~m}$ from the line of the pipe. This fact suggests that the recorded increased temperature in the immediate vicinity of the pipeline contributes to the restoration of the marsh landscape disturbed by the engineering impact. However, the change in climatic parameters is affected by the warming up of the surface layers of the atmosphere. Increasing temperature leads to the acceleration of the process of biogenic relief formation. With the participation of marsh vegetation on the technogenic area, the peat accumulation process is restored. The abovepresented results for points 6 (for four observation periods), 5 and $5 \mathrm{a}$ (for two observation periods) are included in the database of the background temperature indices of the upper part of the annual heat-exchange in the middle taiga subzone of the West Siberian Plain. As a result of the temperature monitoring of marsh landscapes, the main regularities of soil temperature changes were identified on natural marsh landscapes, which depends on the influence of the modern climate. As compared to natural marsh landscapes that are not disturbed by technogenic influence, a higher temperature was observed on soils that are under technogenic objects, which is a factor of the development of heating effects during the engineering development of the territory. Considering the fairly large length of pipeline facilities within the taiga zone of Western Siberia and the results of this research, it is possible to speak of the underestimated contribution of these engineering objects to changes in climatic indices.

\section{Acknowledgements}

The research is funded by the scientific project No. 5.7590.2017 / 8.9. The authors express their gratitude to Olga Yuryevna Talyneva, a staff member of the research laboratory, for assistance in data processing for each temperature well. The reported research was funded by Russian Foundation for Basic Research and the government of the KhantyMansi autonomous district Yugra, grant № 1845-860001

\section{References}

Belyaev, V.I., Bondarovich, A. A. et al. (2017) Temperature Regime of Air and Soil According to the Meteorological and SoilHydrological Monitoring Network in the Kulunda Plain During the Vegetation Periods 2013-2016. Newsletter of the Altai State Agrarian University 3(149): 30-37.

Dyukarev, E. A. (2017) Partitioning of net ecosystem exchange using chamber measurements data from bare soil and vegetated areas. Agricultural and Forest Meteorology, 239: 236-248.

Dyukarev, E.A. (2017) Determining the Components of the Total Ecosystem Exchange of Carbon According to Automatic Chamber Measurements. In Lapshina, E. D., Mironycheva-Tokareva, N. P. (Eds.) Carbon Balance of the Bogs in Western Siberia in the Context of Climate Changes. Proceedings of the International Conference. Tomsk: Publishing House of Tomsk University, pp. 54-56.

Kazantsev, S. A. (2017) Digital Station of Ecological Monitoring. Interexpo GeoSiberia 2(3): 46-49.

Konstantinov, P. Ya., Fedorov, A. N., Michimura, T., Iwahana, G., Yabuki, H., Iijima, Y., Costard F. (2011) Use of automatic recording devices (loggers) for temperature monitoring of permafrost soils. Cryosphere of the Earth XV(1): 23-32. 
Korkin, S. E., Kail, E. K., Mironova, N. S. (2015) Anti-erosion organization of the territory of the Eastern part of the latitudinal segment of $\mathrm{Ob}$ river on the basis of monitoring data. Newsletter of Samara Scientific Center of the Russian Academy of Sciences 17(6): 104-109.

Korkin, S. E., Talyneva, O. Yu., Kail, E. K., Korkina, E. A., Isupov, V. A. (2017) Exogenous geodynamic processes of the central part West Siberia. Proceedings of the International Multidisciplinary Scientific GeoConferences SGEM, Sofia, Bulgaria, pp. 329-335.

Korkin, S. E, Korkina, E. A., Talyneva, O. Y. (2016) Risks of exogeodynamic processes in latitudinal segment of the $\mathrm{Ob}$ river. ARPN Journal of Engineering and Applied Sciences 11(19): 11333-11337.

Korkina, E. A. (2015) Self-Restoration of Middle Priob Soils Disturbed by Technogenesis: Monograph. Nizhnevartovsk: Publishing House of Nizhnevartovsk State University.

Lappalainen, H. K., Kerminen, V. M., Petäjä, T., Alekseychik, P., De Leeuw, G., Järvi, L., Järvinen, H., Kieloaho, A.J., Kujansuu, J., Duplissy, E.M., Mazon, S., Moisseev, D., Pihlatie, M., Sipilä, M., Vesala, T., Zilitinkevich, S., Kulmala, M., Vihma, T., Asmi, E., Laaksonen, A. et al. (2016) Paneurasian experiment (peex): towards a holistic understanding of the feedbacks and interactions in the land-atmosphere-oceansociety continuum in the northern Eurasian region. Atmospheric Chemistry and Physics 16(22): 14421-14461.

Liss, O. L., Abramova, L. I., Avetov, N. A. (2001) Marsh Systems of Western Siberia and Their Conservation Value. Tula: Grif and $\mathrm{K}$.

Lopatina, K.I. (2012) Geoecological foundations for the use of peat bogs and forests of the Middle $\mathrm{Ob}$ Region. Tver: Publishing House "Triada".
Melnikov, V.P., Drozdov, D.S., Pendin, V.V. (2016) Arctic Territories and Cryogenic Risks. Proceedings of the Scientific Congress of the 18th International Scientific and Industrial Forum. Nizhny Novgorod: Nizhny Novgorod State University of Architecture and Civil Engineering, pp. 496-502.

Orekhov, P. T. (2008) Landscape Differentiation of the Temperature Regime of Soils in the Northern Taiga of Western Siberia. Proceedings of the International Conference "Cryogenic Resources of Polar and Mountain Regions. State and Prospects of Engineering Permafrost" (Tyumen, April 21-24, 2008). Tyumen: Earth Cryosphere Institute of the Siberian Branch of the Russian Academy of Sciences, pp. 252-255. Pavlov, A. V. (2008) Monitoring of Permafrost Zone. Novosibirsk: Academic Publishing House "Geo".

Popov, E. Y., Romushkevich, R. A., Popov, Y. A. (2017) Measurements of the Thermal Properties of Rocks on Standard Samples as a Necessary Stage of Thermophysical Studies of Hydrocarbon Deposits. News of Higher Educational Institutions. Geology and Exploration 2: 56-70.

Prokushkin, A. S, Guggenberger, G. (2007) The Role of Climate in the Removal of Dissolved Organic Substances from the Watersheds of the Cryolithozone of Central Siberia. Meteorology and Hydrology 6: 93105.

Sheinkman, V., Sedov, S., Shumilovskikh, L., Korkina, E., Korkin, S., Zinovyev, E., Golyeva, A. (2016) First results from the Late Pleistocene paleosols in northern Western Siberia: Implications for pedogenesis and landscape evolution at the end of MIS3. Quaternary International 418: 132-146.

Sheng, Y., Smith, L. C., MacDonald, G. M., Kremenetski, K. V., Frey, K. E., Velichko, A. A., Lee, M., Beilman, D. W., Dubinin, P. A. (2004) High-resolution GIS-based 
inventory of the West Siberian peat carbon pool. Global Biogeochemical Cycles 18: GB3004.

Vasiliev, A.A., Streletskaya, I.D., Oblogov, G.E., Shirokov, R.S. (2016) Dynamics of the Submarine Permafrost of the Kara Sea in Changing Climatic Conditions. Proceedings of the Fifth Conference of Russian Geocryologists / Part 5. Regional and Historical Geocryology. Part 6. Dynamic geocryology. Geocryological Processes and Phenomena. Part 7. Lithogenetic Geocryology (Cryolithogenesis). Sumy: Limited
Liability Company "University Book" Publishing and Trading House, pp. 26-30.

Wisser, D., Marchenko, S. S., Talbot, J. et al. (2011) Soil temperature response to $21 \mathrm{st}$ century global warming: the role of and some implications for peat carbon in thawing permafrost soils in North America. Earth System Dynamics 2: 121-138.

Zang, Y., Chen, W., Smith, S. L. et al. (2005) Soil temperature in Canada during the twentieth century: Complex responses to anthropogenic climate change. Journal of Geophysical Research Journal of Geophysical. Research, 110: D03112. 